\title{
Cotton farmers' vulnerability to climate change in Gokwe District (Zimbabwe): impact and influencing factors
}

\section{Patrick Gwimbi}

Department of Environmental Health, National University of Lesotho

pgwimbi@hotmail.com

\section{ABSTRACT}

This study analyzes the vulnerability of cotton farmers to climate change in a cotton growing district in Zimbabwe. The vulnerability indicators studied include cotton output and farmers' livelihoods from cotton farming. In order to examine climate variability and change, a time series analysis of two variables: temperature and rainfall was done for a period of 30 years, resulting in graphs of any climate anomalies. Correlation tests between the independent variable (the climate) and the dependent variable (cotton output) were assessed in order to examine the nature and the magnitude of the relationship between the two. The opinions of 100 randomly sampled farmers were analysed in an attempt to verify the climate scenarios and cotton production trends, as well as to understand their adaptation to climate change. Negative rainfall deviations from the long-term mean and positive temperature deviations dominated the climate trend scenarios' results. Cotton production levels declined as precipitation decreased and temperatures increased across the district. The survey revealed that a significant number of farmers believed that temperatures were increasing and precipitation was declining. Farmers' perceptions on whether the climate was changing were greatly influenced by incidences of drought and changes in the seasonal timing of rainfall, and in few cases unusual floods. The majority believed the frequency of droughts was increasing. While farmers were prepared to adapt to changes in climate, their options were very limited. The results show that farmers are highly vulnerable to climate change and that there is a need to invest in climate adaptation strategies, including policies on irrigation and early warning systems to help farmers to cope better and to reduce their vulnerability to climate change.

\section{KEYWORDS}

climate change, rainfall variability, cotton production output, vulnerability

\section{Background}

There is increasing concern in southern Africa regarding the impact of climate change on agriculture (Hulme, 1996:48; Eriksen et al., 2008:7; Mannak, 2009:1). Declining rainfall and 
increasing temperature have had a significant negative impact on agricultural production and on food security (Parry et al., 2007:453). Scientific evidence shows that mean annual temperature has increased; and it is expected to further increase at a rate of $0.05^{\circ} \mathrm{C}$ per decade, while rainfall has been erratic, decreasing on average at a rate of 5 to $10 \%$ per annum, with annual anomalies mostly below normal (Hulme, 1996:48; Kurukulasuriya \& Rosenthal, 2003:3; Kandji et al.,2006:6; Nkomo et.al, 2006:2).

These changes are expected to have serious economic and social impacts, particularly on the rural farmers, many of whom rely on climate-sensitive economic activities, such as rain-fed agriculture (Mannak, 2009:1). According to WMO (2009:4) approximately 70 per cent of Africans or close to 700 million people rely on farming for their livelihood and over 95 per cent of it is rain fed. Changing weather patterns due to climate change are therefore expected to reduce agricultural yields in some areas by as much as 50 per cent as early as 2020 . Agricultural production is the most sensitive to climate because it depends for its production process on natural heat for energy and on water, both climate-related variables. This reinforces the need for the region to consider long-term constraints that any future climate changes may place on agriculture (Eriksen et al., 2008:19; Mannak, 2009:1).

Some of the literature on climate change argue that with adaptation, farmers' vulnerability can be significantly reduced (Kurukulasuriya \& Rosenthal, 2003:5; Odekunle et al., 2007:2112; Gbetibouo, 2009:18). However, limited information exists on the impact, vulnerability and adaptation to climate change, especially at household levels. Given this knowledge gap, there is a need to carefully evaluate the impact of climate change on rural livelihoods in order to provide authorities with timely information for adaptation strategies.

The geographical dimension of climate change impacts on agriculture in Africa is undeniably clear across the continent, as is exemplified by several studies carried out to date (e.g. Hulme, 1996:48; Odekunle et al., 2007:2113; Gbetibouo, 2009:7). Kandji et al. (2006:6) noted that southern Africa has been severely affected by drought since the 1990s, with some parts of southern Zimbabwe and southeastern Botswana receiving rainfall amounts as low as $10 \%$ of the average value during the rainy season. Hulme et al. (2001:150) have likewise noted that parts of East Africa have experienced a negative impact in terms of the availability of water resources, food and agricultural security resulting from increased temperatures and declining rainfall. Odekunle et al. (2007:2104) likewise attributed famine in the savanna regions of $\mathrm{Ni}$ geria to crop failure due to insufficient and untimely rainfall.

Models of climate change, as highlighted by the (Parry et al., 2007:133), indeed confirm these empirical findings and further predict that northern and southern Africa will become drier, while the eastern and western regions of the continent are expected to experience sporadic rainfall and higher temperatures. In a continent whose population is still largely rural and more than $80 \%$ is heavily dependent on rain-fed agriculture, rural livelihoods and food security are highly vulnerable to these climate changes (Kurukulasuriya \& Rosenthal, 2003:7; Odekunle et al., 2007:2103). 
Low levels of technology and limited information on climate change exacerbate farmers' inability to adapt to climate change in these regions (Parry et al., 2007:133; Gbetibouo, 2009:13; Mannak, 2009:1). Whereas most farmers perceive increases in temperature and a decline in rainfall, many have done little to adapt to these changing circumstances (Parry et al., 2007:453). Much of the literature on African farmers' responses to climate change suggests that limited information about climate change and lack of access to institutions dealing with climate change strongly impede farmers' ability to adapt to such climate changes (Eyzaguirre \& Iwanaga, 1996:15; Gbetibouo, 2009:14).

Boko et al. (2007:441), for instance, argue that where farmers enjoy agricultural extension services provided by the government - in the form of loans - and have farmers' networks, they are most likely to initiate climate-change adaptation measures on their farms. Apart from changing their planting and harvesting periods they can also change crop varieties, conserve soil and water and intensify water harvesting and the planting of trees. Nhemachena and Hassan $(2007: 2)$ concur with this view and further argue that the impact of climate change on rural farming communities can be reduced by distributing information about seasonal climate forecasts to farmers on time, so that they can make more informed farming decisions and adapt to changing conditions.

Maddison (2006:10) reinforces these views, blaming national and regional climate forecast and research institutions for poor linkages in terms of the speed and quality of delivering information to local farmers. This is worsened by weak agriculture department extension systems that hamper farmers' uptake of new adaptation technologies (IIED, 2008:7).

It is therefore critical to understand the challenges facing farmers in Africa with regard to climate change adaptation. Evidence on the ground shows complex challenges and barriers; these undermine farmers' willingness and their ability to adapt to climate change (Boko et al., 2007:452; IIED, 2008:9). At household levels some of the constraints have been viewed as a socio-cultural rigidity among farmers themselves, the lack of or restricted access to credit, assets and other resources, as well as any alternative livelihood options in the locality (Sperling and Bouzaher, 2008:588).

At institutional levels, a limited understanding of climate risks and vulnerabilities, together with a lack of policy direction and regulatory guidance still account for constraints faced by local farmers resulting in their failure to adapt to climate change (Boko et al., 2007:453). Increasing the resilience of vulnerable communities needs to be done in order to ensure their access to information on appropriate adaptive practices by vulnerable farmers.

In Zimbabwe, most communal farmers rely on natural rainfall for their farming activities, and are worst affected by climate change (Nyambara, 2003:4). The purpose of this study was to assess climate variability and change and its impact on cotton production in the Gokwe district, and to analyze farmers' vulnerability to such changes, as well as their strategies for adapting to the negative effect of climate change on their livelihoods. Cotton is the major agricultural income earner for farmers in the district. 


\section{Study Area}

Gokwe is the largest district in Zimbabwe and lies to the north west of the country. It is in the country's agro-ecological region three and receives $819 \mathrm{~mm}$ rainfall annually and experiences an annual average temperature of $26^{\circ} \mathrm{C}$. Cotton is the major agricultural income earner for farmers in the Gokwe district. The available literature (Amin, 1992:125; van Oosterhout, 1996:41; Nyambara, 2003:7) shows that the district has experienced an unprecedented cotton boom since independence in 1980. Agriserve and Rancho (1986), as sited by the Government of Zimbabwe (1991:2), noted that the district's contribution to national cotton output fluctuated between 31 and 51 per cent of that in other communal areas. The number of registered cotton growers in Gokwe increased from 24,800 in 1980 to 55,700 in 1984-5, (Nyambara, 2003:8). Cotton production output grew faster than any other crop because of the suitability of farming conditions to cotton.

\section{Materials and Methods}

This study adopted a time-series analysis of two variables: temperature and rainfall to examine the climate variability and change in the district over a period of 30 years. Temperature-rainfall datasets have been used before to analyze climate variation over time and its impact on agriculture. Some of these include the report on climate change in Australia (Hennessy et al., 2008:5), the impact of climate change on rice paddies in Sri Lanka (De Silva et al., 2007:22), climate variability in China (Qian, et al., 2008:4). Godtliebsen et al. (2003:1654) recommend the use of statistical time-series analysis for a wide range of applications connected to studies of climate variability and climate change. CSIRO (2001:6) further noted that temperature-rainfall time series analysis is effective in making climate change projections. While the model has its own shortcomings, there has been enormous confidence in its ability and reliability in terms of simulating the annual cycle of seasonal changes, year-to-year climate variability and extreme events, such as droughts and floods.

Rainfall and temperature data for the period 1977 - 2007 were obtained from the database of the Zimbabwe Department of Meteorological Services. Annual rainfall and temperature deviations from the mean in the district were calculated and plotted to assess years of below-normal and above-normal rainfall. The data series was tested for normality using a Statistical Package for the Social Sciences (SPSS).

To accurately predict the long-term rainfall and temperature trends and to determine the average seasonal variation the data was smoothed using the means from three consecutive years. The resultant time-series graphs were compared to the national average annual data for the same period.

To evaluate the contribution of each climatic variable in explaining cotton output, the coefficient of determination ( $\mathrm{r} 2$ ) was used. The coefficient of determination described the amount of variability in cotton production which could be explained by climate variables.

Results from household surveys were used to verify the climate change impact and cotton output scenarios, as well as to generate information on farmers' perceptions of the changes in 


\section{Patrick Gwimbi}

temperature and rainfall in the district and their adaptation strategies to cope with climate change.

\section{Fig 1. Annual rainfall anomalies for Gokwe district}

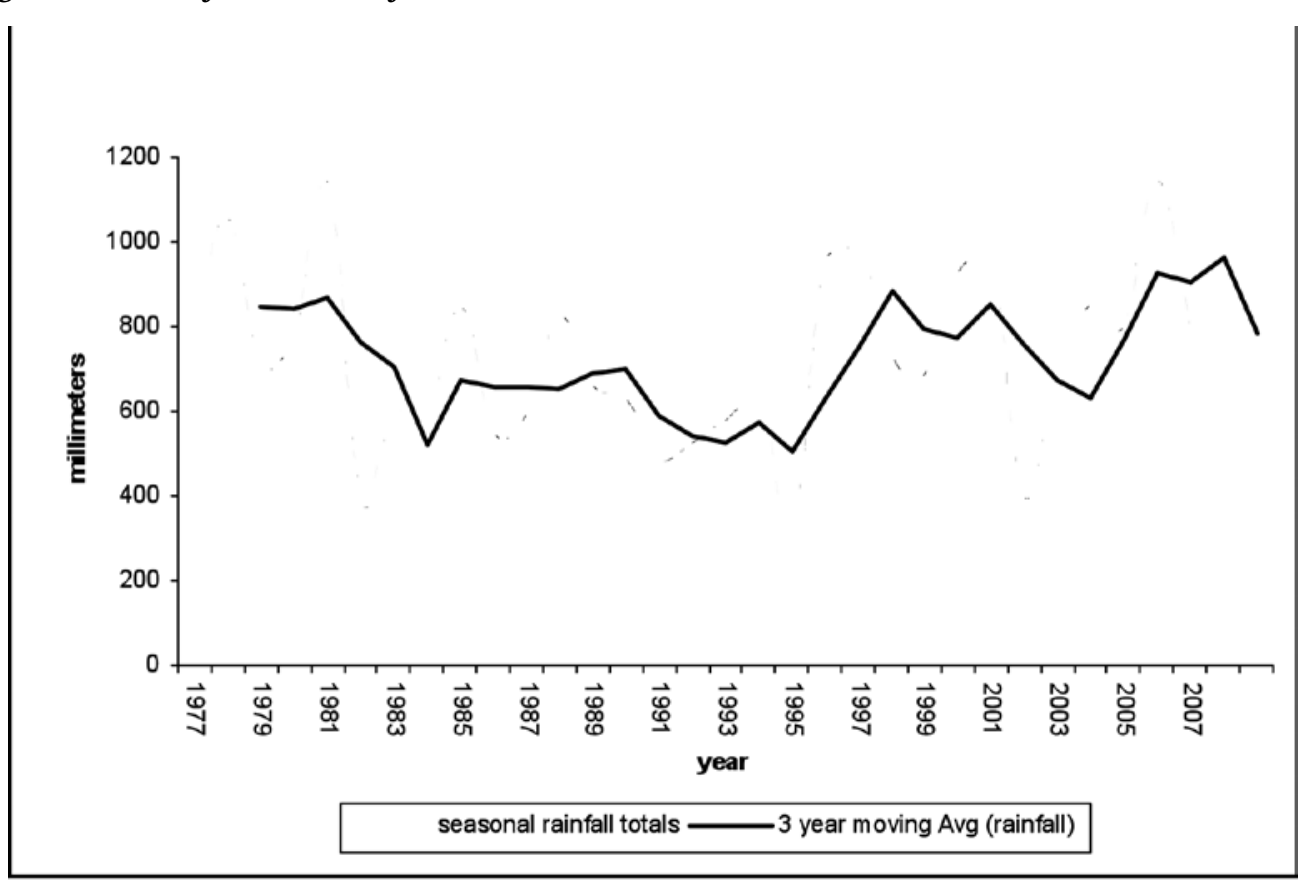

Source: Zimbabwe Department of Meteorological Services

\section{Results and Discussion}

\section{Climate variability and farmers' vulnerability in the district}

Figure 1 presents a graphical display of the seasonal rainfall totals as deviations above or below the mean of $819 \mathrm{~mm}$ for the district. The data shows that there were dry years with rainfall below long term mean of $819 \mathrm{~mm}$ and wet years with rainfall above the same long term mean. Generally clear oscillations of dry years were observed from the 1980s to the late 1990s. The variation pattern seemed to follow the El Nino and Southern Oscillation and the La Nina episodes. Three extreme dry points were detected during the 1981/2 and 1991/2 and 2001/2 seasons at which the rainfall was below normal. The district was drier than normal during this period, with an average of $130 \mathrm{~mm}$ less rainfall than normal. The wettest periods were in 1980 and the Cyclones Eline and Japhet-related floods of 2000 and 2003 respectively.

The most significant rainfall variation was a long-term reduction in rainfall particularly after 1980. The extended periods of below-normal rainfall were evident, even at national level in the 1990s and post-2003.

There were anomalies in the average temperatures in the district, especially from 1980 onwards (Figure 2). This was consistent with the general view of an increasing temperature at an average of $0.05^{\circ} \mathrm{C}$ per decade in Zimbabwe (Kandji et al., 2006:6). For the district the significant temperature increases did not differ from those of the national average. 
Fig 2. Temperature anomalies in Gokwe for the past 30 years

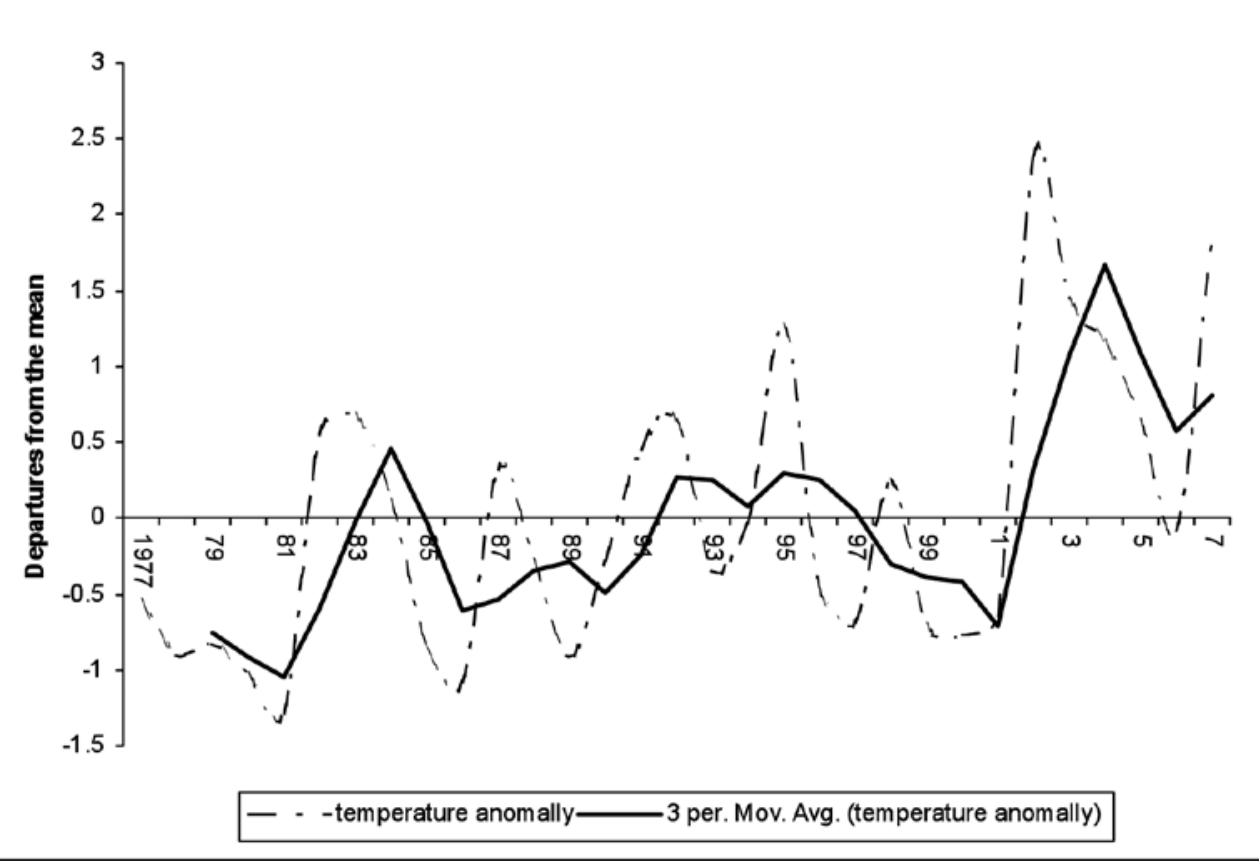

Source: Zimbabwe Department of Meteorological Services

Fig 3. Rainfall and cotton output scenarios in Gokwe District

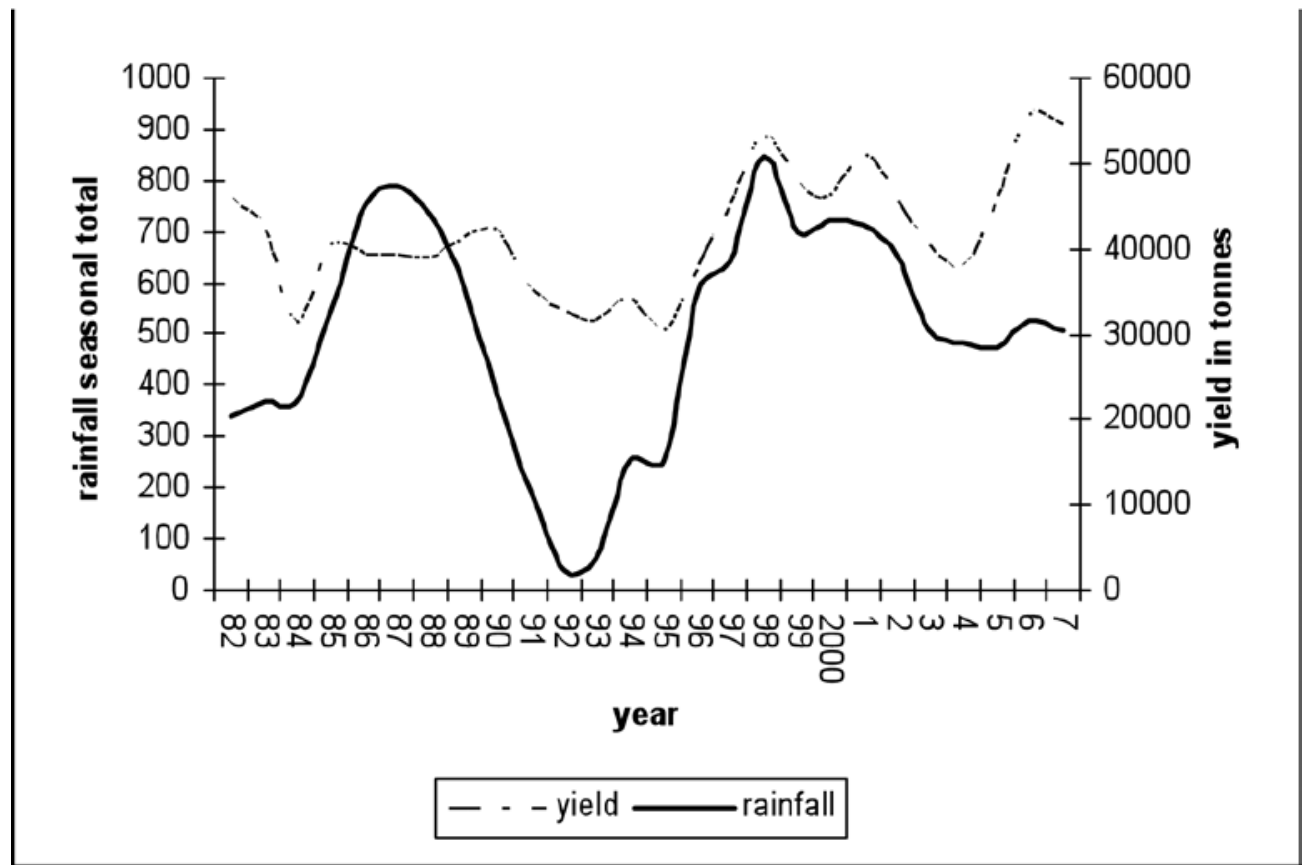

Source: Zimbabwe Department of Meteorological Services 


\section{Patrick Gwimbi}

The effect of drought on temperature was evident through a strong negative association between temperature anomalies and rainfall anomalies. The droughts of 1981-82, 1991-1992 and 2001 - 2002 were associated with low levels of cotton output (Figure 3). In the $1991-$ 1992 season for example, a more than $80 \%$ decrease in precipitation resulted in a $38 \%$ decrease in cotton delivered to the Cotton Marketing Board.

Farmers perceived years of high rainfall to be linked to years of higher harvest. All farmers in the survey pointed to the drought years of 1981-82 and 1991-92 seasons, as having severely reduced their cotton output.

When comparing cotton delivered to the market with mean annual rainfall, $64 \%(\mathrm{r} 2=0.64)$ of the changes in cotton output could be explained by the rainfall trend pattern in the district. The correlation coefficient between cotton output and mean rainfall was positive and statistically significant $(\mathrm{r}=0.8, \mathrm{p}<0.05)$. Temperature increases also affected cotton production output negatively $(\mathrm{r}=-0.4, \mathrm{p}<0.05)$, as demand for water during the dry years increased, due to increased evapotranspiration.

The rainfall decrease did not just impact on cotton output alone, but also on social and human capital. Incidences of children dropping out of school because parents could not afford to pay their school fees $(23 \%$ of respondents, $\mathrm{N}=100)$, migration to urban areas by the productive age groups (15\%) in search of alternative means of generating income and increased antisocial behaviour practices $(21 \%)$ at Gokwe town centre were discretely mentioned by farmers as some of the resultant effects of the low cotton output.

The year 2005 recorded a smaller cotton harvest, as field visits confirmed (Figure 4). Cotton production, according to the delivery records, is estimated to have declined by $30 \%$.

Fig 4. Drought impact on cotton in 2005 (Date 23 April 2005)

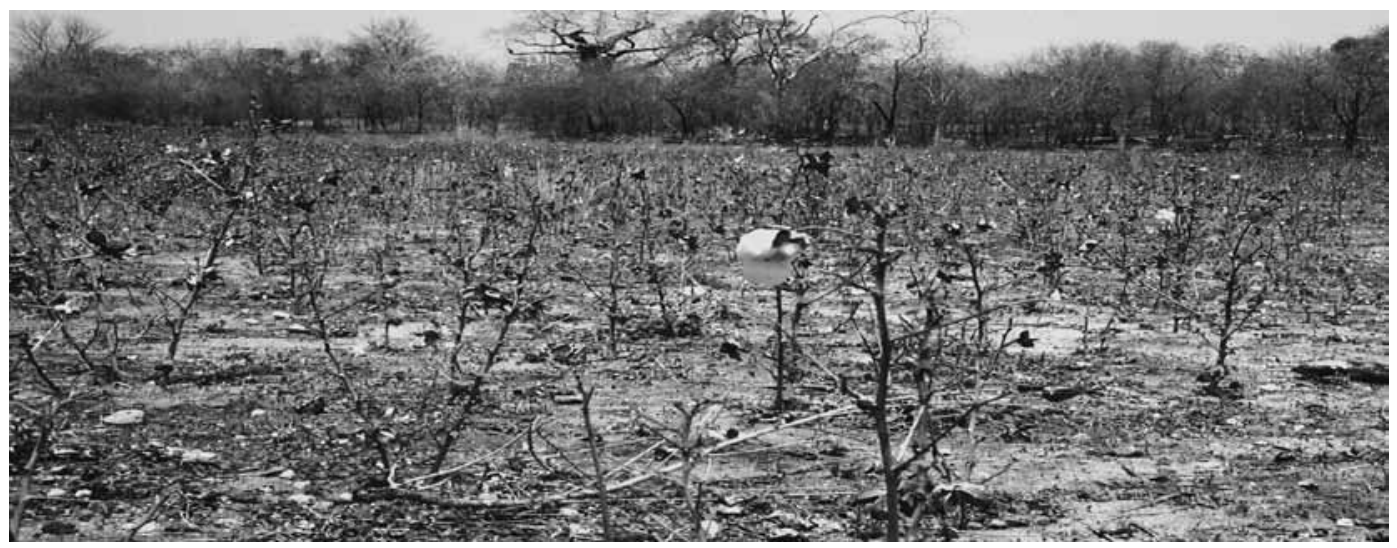

Source: Gwimbi (2005)

\section{Farmers' Perceptions of Climate Change}

Farmers' perceptions of climate change were compared to the climatic data records and the two results appeared to agree (Figure 5). About 60 percent of the farmers noted an increase in 
temperature and a decline in rainfall. This perception was in agreement with the statistical records (Figure 5), which showed a temperature increase occurring consistently over the years, while rainfall decreased significantly.

Fig 5. Comparison between farmers' perceptions and the actual records.
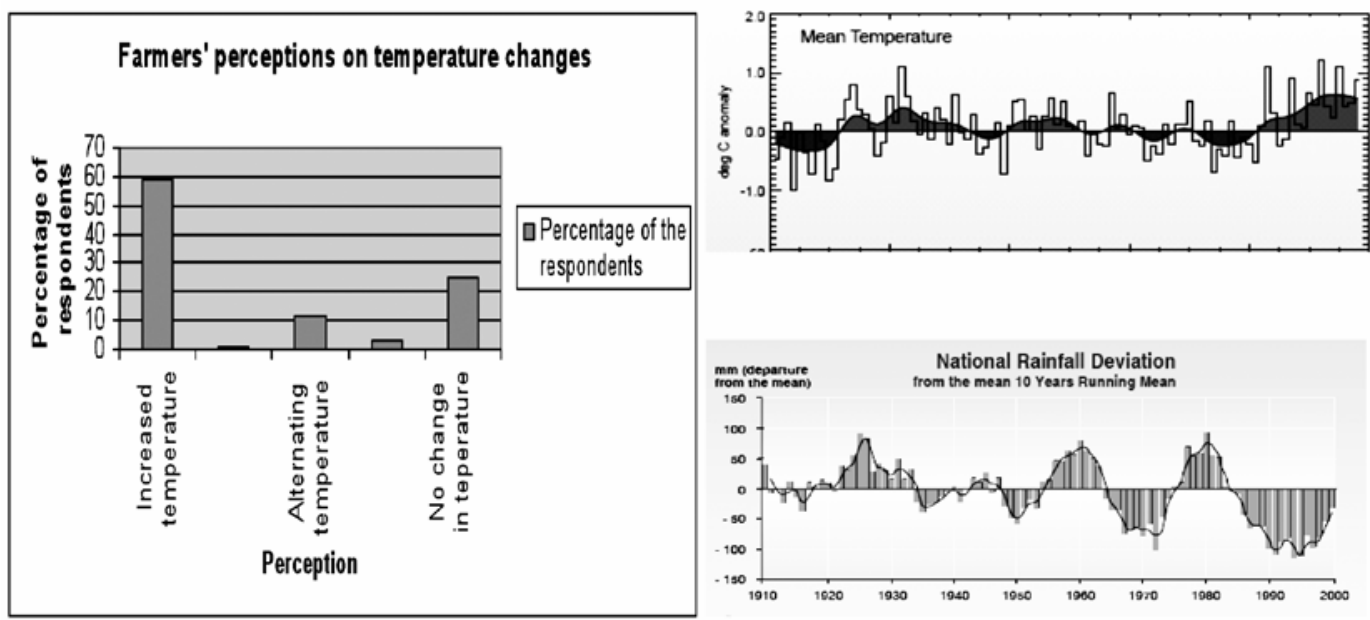

Source: Zimbabwe Department of Meteorological Services at: http://weather.utande.co.zw/climate/climatechange.htm

A small but significant percentage of the farmers (15\%) were of the view that both rainfall and temperatures were alternating between above-normal and below-normal levels, while $25 \%$ reported that there was no change. Overall, as many as $75 \%$ of the farmers reported a greater frequency of water-deficit years, later onset of the rainy season and premature end of the rains.

The high proportion of farmers noticing a decrease in precipitation could be attributed to the substantial decline in cotton output realized from farming over the years, despite regular other inputs into farming. There was a general agreement among all the respondents interviewed that the rainfall was no longer what it used to be. The worst drought experiences in the district were in the early 1980s, 1991-92 and 2001-2 seasons. These were still fresh in the memories of farmers who had lost most of their produce to the drought.

\section{Farmers' Adaptation to Climate Change}

The preferred adaptation measures identified are shown in Figure 6. More than $65 \%$ of the farmers were of the view that their solution to climate change depended on the use of irrigation $(31 \%)$, diversification into cotton varieties that were more drought-resistant ones $(10 \%)$, diversifying into other crops $(11 \%)$, or alternatively, timing the planting period to coincide with the onset of the rains (14\%).

The majority of the respondents (71\%) opted for short-season hybrid varieties because the growing season was getting shorter. Farmers noted that rainfall patterns had hindered the growing of long-season cotton varieties. 


\section{Patrick Gwimbi}

A significant, though small, number of farmers (15\%) however maintained that nothing could be done (Figure 4). It was however noted that this group had little or no information in regard to climate change.

Fig 6. Farmers' preferred adaptation to climate change

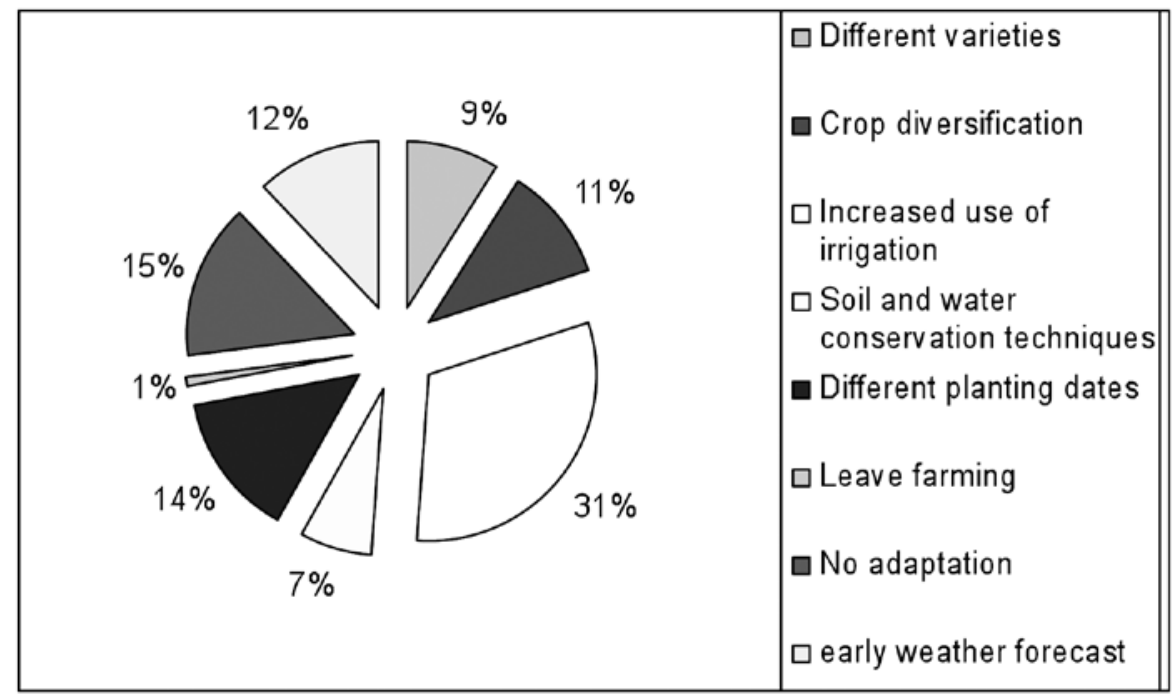

Source: Gwimbi (2005)

No evidence was however found that supported the view that farmers were implementing any adaptation on the ground, despite the farmers highlighting their preferred coping strategies to climate change. Figure 7 highlights the constraints faced by farmers in adapting to climate change.

Fig 7. Information concerning climate change forecasting and adaptation options among farmers

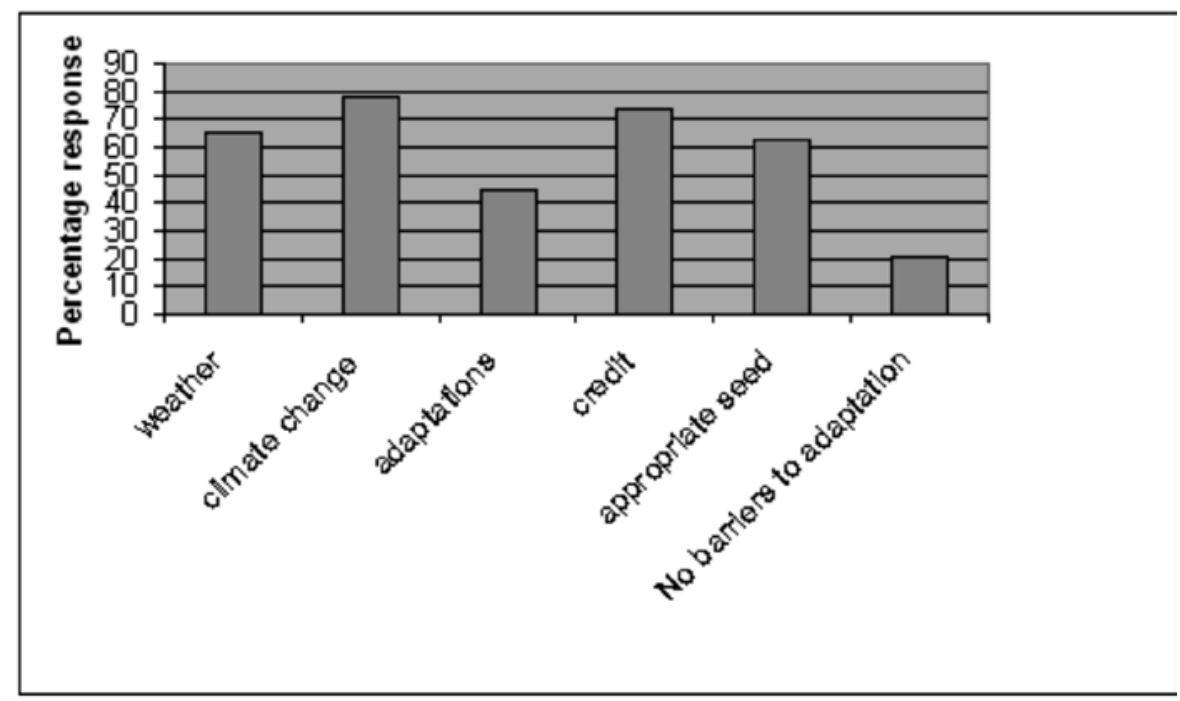


More than $70 \%$ of the farmers surveyed highlighted the lack of access to timely weather forecasts, climate change information and credit facilities that were needed to motivate them to engage in water-conservation strategies (Figure 7). Poverty posed a major obstacle for farmers that did not have the necessary technology and resources to change or to adapt to the rigours of climate change.

\section{Conclusion and recommendations}

In Gokwe district, agriculture of any kind is strongly influenced by the availability of water. Changes in the seasonal precipitation pattern therefore affect farmers significantly. This study assessed the vulnerability of cotton farmers and their ability to adapt to climate changes. The results show that farmers are highly vulnerable to climate change, especially to declining rainfall.

Whilst at regional and national levels there is an increasing amount of climate information available in the form of weather forecasts, seasonal forecasts and climate change scenarios, this study noted that this information was not always delivered to potential end users in an accessible way, so that farmers would be able to interpret its relevance and be able to use it effectively.

There is a need to ensure that planning processes at all levels integrate climate change risks and build public support for climate policies that will enable farmers to meet the objective of limiting the negative effects of climate change, and thereby reduce their vulnerability. Climate information itself needs to be delivered and disseminated in ways that increase its practical value to the farmers. For this to be achieved co-ordination across all sectors is required.

New irrigation schemes are likely to be effective, especially when combined with better access to drought-resistant cotton varieties. Consequently, the study recommends investment in irrigation and early-warning systems to help farmers to cope better and reduce their vulnerability to climate change in the future.

\section{References}

AGRISERVE (PVT) LTD. \& RANCHO COMPANY, 1986. The Impact of the Sanyati Gin on Cotton Marketing Production: Report to the United States Agency for International Development and Cotton Marketing Board, Harare.

AMIN, N. 1992. State and Peasantry in Zimbabwe since independence. European Journal of Development Research, 4 (1):112-162, June.

BOKO, M., NIANG , I. NYONG, A. VOGEL , C., GITHEKO , A. M., MEDANY , B.,OSMANELASHA , R., YANDA, P., 2007. Africa. In: PARRY, M. L., CANZIANI, O. F., PALUTIKOF, J. P., VAN DER LINDEN, P. J., HANSON, C. (eds). Climate change 2007: impacts, adaptation and vulnerability. Contribution of Working Group II to the Fourth Assessment Report of the Intergovernmental Panel on Climate Change. Cambridge, United Kingdom: Cambridge University Press. 433-467 p.

CSIRO, 2001. Climate change projections for Australia. CSIRO Atmospheric Research, Aspendale. [Web:] http://www.dar.csiro.au/publications/projections 2001.pdf. Date of access: 31 Jul. 2009. 


\section{Patrick Gwimbi}

DE SILVA, C. S. WEATHERHEAD, E.K., KNOX, J.W., RODRIGUEZ-DIAZ, J.A., 2007. Predicting the impacts of climate change-A case study of paddy irrigation water requirements in Sri Lanka. Agricultural Water Management, 93(1): 19-29, October.

ERIKSEN S., O'BRIEN K., ROSENTRATER, L., 2008. Climate Change in Eastern and Southern Africa: Impacts, Vulnerability and Adaptation. GECHS Report 2008:2.

[Web:] http://www.gechs.org/downloads/reports/2008-2.pdf. Date of access: 31 Jul. 2009.

EYZAGUIRRE, P., IWANAGA, M., 1996. Farmers contribution to maintaining genetic diversity in crops and its role within the total genetic resources system. In: EYZAGUIRRE, P. and IWANAGA, M. (eds). Participatory Plant Breeding. IPGRI, Rome. 9-18 p.

GBETIBOUO, G. A., 2009. Understanding Farmers' Perceptions and Adaptations to Climate Change and Variability: The Case of the Limpopo Basin, South Africa, IFPRI. Discussion Paper. Washington, DC: International Food Policy Research Institute.

GODTLIEBSEN, F., OLSEN, L. R., WINTHER, J. G., 2003. Recent developments in statistical time series analysis: Examples of use in climate research. Geophysical Research Letters, 30(12): 1654, June.

GOVERNMENT OF ZIMBABWE, 1991. Cotton-Sub Sector Study. Final Report, Technical Annexes. Harare: Government Publications.

HENNESSY, K., FAWCETT, R., KIRONO, D., MPELASOKA, F., JONES, D.,

BATHOLS, J., WHETTON, P., STAFFORD SMITH, M., HOWDEN, M., MITCHELL, C., PLUMMER, N. 2008. An assessment of the impact of climate change on the nature and frequency of exceptional climatic events. [Web:] http://www.daff.gov.au/_data/assets/pdf_file/0007/721285/csirobom-report-future-droughts.pdf. Date of access: 03 Aug.2009.

HULME, M., R., DOHERTY, T., NGARA, M., NEW, D., LISTER. 2001. African climate change: 1900 - 2100. Climate Research 17. 145-168, April.

HULME, M. 1996. Climate Change and southern Africa: an exploration of some potential impacts and implications in the SADC region. A report commissioned by WWF International and Co-ordinated by the Climate Research Unit, UEA, Norwich, U.K.

IIED. 2008. Adaptation to climate change in Africa (a study for the Nordic African Ministers of Foreign Affairs Forum) International Institute for Environment and Development, London.

KANDJI, S. T., VERCHOT, L., MACKENSEN, J., 2006. Climate Change and Variability in Southern Africa: Impacts and Adaptation in the Agricultural Sector.

[Web:] www.unep.org/.../Climate_Change_and_Variability_in_the_Southern_Africa.pdf . Date of access: 25 August 2009

KURUKULASURIYA, P. \& ROSENTHAL, S. 2003. Climate Change and Agriculture: A Review of Impacts and Adaptations. Environment Department Papers, Climate Change Series. Paper 91. The World Bank, Washington D.C.

MADDISON, D., 2006. The perception of and adaptation to climate change in Africa.

CEEPA, Discussion Paper No. 10. Centre for Environmental Economics and Policy in Africa, University of Pretoria, South Africa.

MANNAK, M. 2009. Africa: Climate Change threatens food security. [Web:] http://www.fanrpan.org/ documents/d00639/. Date of access: 31 Jul. 2009.

NHEMACHENA, C. \& HASSAN, R. 2007. Micro-level analysis of farmers' adaptation to climate 
change in Southern Africa. IFPRI Discussion Paper No. 00714. International Food Policy Research Institute, Washington, D.C.

NKOMO, J. C., NYONG, A. O., KULINDWA, K. 2006. The Impacts of Climate Change in Africa. Paper submitted to The Stern Review on the Economics of Climate Change. [Web:] www.hm-treasury.gov.uk/.../Chapter_5_The_Impacts_of_Climate_Change_in_frica-5.pdf. date of access: 14 Aug. 2009.

NYAMBARA, P.S. 2003. Rural Landlords, Rural Tenants, and the Sharecropping Complex in Gokwe, Northwestern Zimbabwe, 1980s-2002. University of Zimbabwe, Centre for Applied Social Sciences.

ODEKUNLE T. O., ORINMOOGUNJE I. O. O., AYANLADE A., 2007. Application of GIS to assess rainfall variability impacts on crop yield in Guinean Savanna part of Nigeria. African Journal of Biotechnology 6 (18):2100-2113, September.

PARRY, M.L., CANZIANI, O.F., PALUTIKOF, J.P., VAN DER LINDEN P.J. AND HANSON, C.E. eds. 2007 Contribution of Working Group II to the Fourth Assessment Report of the Intergovernmental Panel on Climate Change. Cambridge University Press, Cambridge, UK.

QIAN, W., DING, T., FU, J., LIN X., ZHU, Y. 2008. Review on the Data Application and Climate Variability in China for Various Timescales.Advances in Climate Change Research, 4 (Suppl.): 1-6, March.

SPERLING, F. \& BOUZAHER, A. 2008. Climate change adaptation in the sub-Saharan Africa region. Environment Matters, World Bank, Washington.

VAN OOSTERHOUT, S., 1996. What does in situ conservation mean in the Life of Small-scale Farmers? Examples from Zimbabwe's Communal Areas. In: Sperling, L. and Loevinsohn, M. (eds). Using Diversity: Enhancing and Maintaining Genetic Resources On-farm. IDRC, New Delhi. 35- 52 p. WMO 2009. Improving weather monitoring in Africa. [Web:] http://www.wmo.int/pages/publications/meteoworld/activities_en.html\#africa. Date of access: 25 Sept. 2009.

ZIMBABWE DEPARTMENT OF METEOROLOGICAL SERVICES. 2009. [Web]: http://weather. utande.co.zw/climate/climatechange.htm. Date of access: 25 Feb. 2009. 